\title{
Positron emission tomography imaging in gliomas
}

\author{
Assimakis Assimakopoulos ${ }^{1}$, Konstantinos Polyzoidis ${ }^{1,2}$, Chrissa Sioka ${ }^{1}$ \\ ${ }^{1}$ Neurosurgical Research Institute, University of Ioannina, 45500 Ioannina, Ioannina, Greece. \\ ${ }^{2}$ Department of Neurosurgery, Aristotle University of Thessaloniki, 54124 Thessaloniki, Thessaloniki, Greece.
}

\section{A B S T R A C T}

Glioma, the most frequent primary brain tumor in adults, is a highly infiltrative tumor exhibiting resistance to most treatments and associated with short survival of patients. Positron emission tomography (PET) imaging using various tracers takes advantage of the increased metabolic rate of neoplastic cells, in order to detect tumors and validate the treatment response. The most frequently used PET tracer, the (18)F-fluorodeoxyglucose (FDG), is useful during the initial and follow-up assessment of patients with gliomas because it can assist in the selection of the initial biopsy site and to assess early response to a given therapeutic intervention. Furthermore, when there is tumor re-growth after an initial remission, FDG-PET can differentiate between true tumor recurrence versus necrosis from radiation therapy. Newly developed PET tracers may exhibit better sensitivity than FDG to diagnose primary brain tumors, but may occasionally produce false positive results in various conditions. In any event, PET is a useful tool in patients with central nervous system cancer during both initial assessment and follow-up.

Key words: Brain tumor, cancer, glioma, positron emission tomography

\section{INTRODUCTION}

Gliomas represent the most common primary brain tumors, with poor prognosis even with aggressive therapies such as various combinations of surgery, radiation therapy and chemotherapies. ${ }^{[1,2]}$ Earlier response and progression criteria in recurrent glioma relied on changes in the contrast enhancing magnetic resonance imaging (MRI) ${ }^{[3,4]}$ however, the dramatic response rates seen in therapies involving antiangiogenic therapies as well as other insufficiencies of the previous criteria resulted in development of updated response criteria that take into account the nonenhancing component of the tumor as well as other critical parameters. ${ }^{[4,5]}$ The newly described response assessment in neuro-oncology (RANO) criteria includes comprehensive recommendations to assess response to a therapy taking into account various issues in gliomas, such as imaging changes postsurgical resection of a tumor or locally delivered therapies, issues-related to contrast enhancement of previously unenhanced areas as well as clinical parameters. ${ }^{[6]}$ This field is still

\begin{tabular}{|l|l|}
\hline \multicolumn{2}{|c|}{ Access this article online } \\
\hline Quick Response Code: & \\
\hline & Website: \\
\hline & www.nnjournal.net \\
\cline { 2 - 3 } & DOI: \\
\hline
\end{tabular}

evolving since in a recent report the change in ADC histogram skewness may be more sensitive than the response assessment in RANO criteria for evaluation of antiangiogenic therapy. ${ }^{[7]}$

Nuclear medicine imaging such as positron emission tomography (PET) and single photon emission computed tomography (SPECT) combined with CT are useful for diagnosis and management of a variety of neurological diseases and cancers. ${ }^{[8]}$ SPECT and PET scans may be utilized to assess brain tumor biologic behavior, ${ }^{[9]}$ distinction of radiation-induced necrosis from tumor recurrence and estimation of overall prognosis. ${ }^{[10]}$ Increased tumor uptake of (99 m) Tc-tetrofosmin in SPECT correlated with aggressive behavior and may be an independent prognostic factor in patients with malignant glioma. ${ }^{[11]}$

In this article, we present an evidence-based practical approach for the use of PET/CT during evaluation and therapy of patients with a malignant primary brain tumor. We reviewed published papers during the last decade and included some older key references and our own experience.

\section{(18)F-FLURODEOXYGLUCOSE POSITRON EMISSION TOMOGRAPHY}

(18)F-flurodeoxyglucose (FDG) PET takes advantage of the increased glucose uptake, a characteristic of

Corresponding Author: Dr. Chrissa Sioka, Neurosurgical Research Institute, University of loannina, 45500 loannina, loannina, Greece. E-mail: csioka@yahoo.com 
tumor cells, in order to detect tumors and validate the treatment response [Table 1].

Hypometabolism on FDG PET in brain lesions and stability over a period is indicative of nonmalignancy. ${ }^{[24]}$ When it is difficult to differentiate preoperatively a primary brain tumor from metastasis, ${ }^{[25]}$ FDG PET may be helpful in depicting areas of systemic involvement, ${ }^{[26]}$ or localizing the primary cancer site. ${ }^{[27,28]}$ Occasionally, patients may present with brain lesions, radiologically compatible with brain metastases that after biopsy are proven to be multifocal gliomas. ${ }^{[29,30]}$ In such cases, FDG PET may aid in pinpointing the area of stereotactic biopsy, ${ }^{[31,32]}$ assist in tumor delineation during radiotherapy planning ${ }^{[33]}$ and assessment of treatment response. ${ }^{[34]}$

In a study of 81 recurrent glioma patients studied by FDG PET, it was found that the higher the FDG uptake by the tumor it was associated with worse survival. ${ }^{[35]}$ In addition, pretreatment uptake of FDG in 25 patients with recurrent gliomas subsequently

\begin{tabular}{|c|c|c|c|c|}
\hline Study & No. of patients & Reason for the exam & Results (\%) & Study conclusion \\
\hline Colavolpe et al. ${ }^{[12]}$ & $\begin{array}{l}25 \text { patients with } \\
\text { recurrent glioma }\end{array}$ & $\begin{array}{l}\text { To assess utility of FDG } \\
\text { PET/CT in patients } \\
\text { receiving bevacizumab and } \\
\text { irinotecan therapy }\end{array}$ & $\begin{array}{l}\text { FDG uptake was the most } \\
\text { powerful predictor of both PFS } \\
\text { and OS using the RANO criteria }\end{array}$ & $\begin{array}{l}\text { Pretreatment FDG PET } \\
\text { predicts survival in } \\
\text { recurrent glioma patients } \\
\text { following anti-angiogenic } \\
\text { therapy }\end{array}$ \\
\hline Santra et al. ${ }^{[13]}$ & $\begin{array}{l}90 \text { patients with } \\
\text { possible recurrent } \\
\text { glioma }\end{array}$ & $\begin{array}{l}\text { To compare FDG PET/CT } \\
\text { with contrast MRI }\end{array}$ & $\begin{array}{l}\text { PET sensitivity: } 70 \\
\text { Specificity: } 97 \\
\text { MRI sensitivity: } 95 \\
\text { Specificity: } 23\end{array}$ & $\begin{array}{l}\text { FDG PET/CT was an } \\
\text { accurate modality to } \\
\text { detect glioma recurrence }\end{array}$ \\
\hline Borbely et al..$^{[14]}$ & $\begin{array}{l}59 \text { patients with } \\
\text { primary and recurrent } \\
\text { brain gliomas ( } 50 \text { had } \\
\text { MET PET; } 33 \text { had } \\
\text { FDG PET) }\end{array}$ & $\begin{array}{l}\text { To compare FDG PET with } \\
\text { MET PET for in vivo grading } \\
\text { of malignant gliomas }\end{array}$ & $\begin{array}{l}\text { FDG PET superior to MET PET } \\
\text { for grading of gliomas }\end{array}$ & $\begin{array}{l}\text { FDG PET recommended } \\
\text { for grading but MET } \\
\text { PET may be used for } \\
\text { assessing the extent of } \\
\text { the tumor }\end{array}$ \\
\hline Singhal et al..$^{[15]}$ & $\begin{array}{l}102 \text { patients with } \\
\text { confirmed gliomas } \\
\text { were followed for } \\
\text { an average of } 34.6 \\
\text { months after PET }\end{array}$ & $\begin{array}{l}\text { To compare FDG PET with } \\
\text { MET PET and MRI }\end{array}$ & $\begin{array}{l}\text { MET PET superior to FDG PET } \\
\text { and MRI in predicting survival in } \\
\text { low-grade gliomas }\end{array}$ & $\begin{array}{l}\text { For low grade gliomas } \\
\text { MET PET preferred to } \\
\text { FDG PET }\end{array}$ \\
\hline Yamaguchi et al..$^{[16]}$ & $\begin{array}{l}26 \text { patients with } \\
\text { untreated or recurrent } \\
\text { adult gliomas had } \\
\text { preoperative FDG } \\
(n=25) \text { and/or MET } \\
(n=22) \text { PET }\end{array}$ & $\begin{array}{l}\text { To compare FDG PET with } \\
\text { MET PET }\end{array}$ & $\begin{array}{l}\text { FDG better for tumor grade } \\
\text { MET better for delineating the } \\
\text { extent of the tumor }\end{array}$ & $\begin{array}{l}\text { Both tracers complement } \\
\text { each other to plan } \\
\text { the extend of tumor } \\
\text { resection }\end{array}$ \\
\hline Tripathi et al..17] & $\begin{array}{l}15 \text { patients with } \\
\text { untreated or recurrent } \\
\text { low grade gliomas }\end{array}$ & $\begin{array}{l}\text { To compare FDG PET with } \\
\text { FDOPA PET and FLT PET }\end{array}$ & $\begin{array}{l}\text { FDOPA PET superior to both } \\
\text { FDG and FLT PET for detection } \\
\text { of low grade gliomas }\end{array}$ & $\begin{array}{l}\text { FDOPA PET should be } \\
\text { the radiotracer of choice } \\
\text { for low grade glioma }\end{array}$ \\
\hline Chen et al. ${ }^{[18]}$ & $\begin{array}{l}25 \text { patients with with } \\
\text { untreated or recurrent } \\
\text { adult gliomas }\end{array}$ & $\begin{array}{l}\text { To compare FDG PET with } \\
\text { FLT PET }\end{array}$ & $\begin{array}{l}\text { FLT PET better to image } \\
\text { recurrent high-grade tumors, to } \\
\text { correlate with Ki- } 67 \text { values, and } \\
\text { predict tumor progression and } \\
\text { survival }\end{array}$ & $\begin{array}{l}\text { FLT a promising tracer } \\
\text { of proliferation in } \\
\text { high-grade gliomas }\end{array}$ \\
\hline Enslow et al..$^{[19]}$ & $\begin{array}{l}15 \text { recurrent glioma } \\
\text { patients }\end{array}$ & $\begin{array}{l}\text { To compare FDG PET with } \\
\text { FLT PET }\end{array}$ & $\begin{array}{l}\text { Both FDG PET and FLT PET } \\
\text { could differentiate between tumor } \\
\text { recurrence and radiation necrosis }\end{array}$ & $\begin{array}{l}\text { FLT PET offers no } \\
\text { advantage over FDG } \\
\text { PET }\end{array}$ \\
\hline Karunanithi et al..$^{[20]}$ & $\begin{array}{l}28 \text { patients with } \\
\text { recurrent gliomas }\end{array}$ & $\begin{array}{l}\text { To compare FDG PET with } \\
\text { FDOPA PET for diagnosis } \\
\text { of recurrence }\end{array}$ & $\begin{array}{l}\text { FDG sensitivity: } 47.6 \\
\text { FDG specificity: } 100 \\
\text { FDOPA sensitivity: } 100 \\
\text { FDOPA specificity: } 85.7\end{array}$ & $\begin{array}{l}\text { The difference between } \\
\text { FDOPA and FDG PET } \\
\text { was significant for low } \\
\text { grade glioma but not for } \\
\text { high grade tumors }\end{array}$ \\
\hline Tripathi et al..[21] & $\begin{array}{l}35 \text { patients with } \\
\text { recurrent glioma }\end{array}$ & $\begin{array}{l}\text { To compare FDG PET with } \\
\text { MET PET }\end{array}$ & $\begin{array}{l}\text { FDG sensitivity: } 81.2 \\
\text { FDG specificity: } 88.9 \\
\text { MET sensitivity: } 94.7 \\
\text { MET specificity: } 88.9\end{array}$ & $\begin{array}{l}\text { MET should be the } \\
\text { radiotracer of choice for } \\
\text { recurrent gliomas }\end{array}$ \\
\hline Potzi et al. ${ }^{[22]}$ & $\begin{array}{l}28 \text { patients with } \\
\text { recurrent GBM }\end{array}$ & $\begin{array}{l}\text { To evaluate FDG and MET } \\
\text { PET for recurrent glioma }\end{array}$ & & $\begin{array}{l}\text { FDG PET of limited value; } \\
\text { MET PET not superior to } \\
\text { conventional imaging }\end{array}$ \\
\hline Nihashi et al. ${ }^{[23]}$ & $\begin{array}{l}\text { Meta-analysis of } 26 \\
\text { heterogenous studies }\end{array}$ & $\begin{array}{l}\text { To evaluate the diagnostic } \\
\text { accuracy of PET and } \\
\text { compare it with conventional } \\
\text { imaging modalities }\end{array}$ & $\begin{array}{l}\text { FDG PET and MET PET } \\
\text { with acceptable accuracy for } \\
\text { diagnosing recurrent glioma }\end{array}$ & $\begin{array}{l}\text { Prospective studies } \\
\text { with direct comparisons } \\
\text { between various imaging } \\
\text { modalities required }\end{array}$ \\
\hline
\end{tabular}

PET: Positron emission tomography; CT: Computed tomography; MRI: Magnetic resonance imaging; RANO: Response assessment in neuro-oncology;

FDG: (18)F-flurodeoxyglucose; FET: O-(2-(18)F-fluoroethyl)-I-tyrosine; GBM: Glioblastomamultiforme; MET: (11)C-methionine; FDOPA: (18)F-FDOPA; FLT: 3'-Fluoro-3' deoxythymidine; PFS: Progression-free survival; OS: Overall survival; HGG: WHO grades III or IV; LGG: WHO grades I or II 
treatment with bevacizumab and irinotecan predicted response to the treatment and correlated with overall survival. ${ }^{[12]}$ Similar predictive value of FDG-PET was reported with other therapies in glioma patients. ${ }^{[36]}$ FDG PET compared to MRI scans with and without contrast enhancement had much higher specificity (97\% vs. 23\%) for detection of recurrence in 90 glioma patients clinically suspicious of tumor growth. ${ }^{[13]}$

\section{OTHER POSITRON EMISSION TOMOGRAPHY TRACERS AND COMPARISON WITH (18)F-FLURODEOXYGLUCOSE}

During the last several years, new PET tracers have been developed for a wide range of biological targets [Table 2]. ${ }^{[37]}$

PET of amino acid transport and metabolism could be a reliable method in assessing a metabolic response after treatment of a tumor or in establishing a treatment-related effect, depending on the rate of the tracer uptake by tumor. Employment of imaging amino acid transport may prove to have an important clinical role in the management of brain tumor patients since it may result in changes in therapeutic management. ${ }^{[62]}$

For example, application of O-(2-(18)F-fluoroethyl)L-tyrosine (FET) PET/CT in newly diagnosed brain tumors could predict their biologic behavior in most of the cases. ${ }^{[48,52,63]}$ FET represents an artificial amino acid not incorporates into proteins but transports into active glioma cells. ${ }^{[46]}$ FET-PET may be more accurate than FDG-PET for differentiation of malignant gliomas from low-grade gliomas, ${ }^{[64,65]}$ by their low FET uptake on PET in the low-grade tumors. ${ }^{[66,67]}$ Thus, in a study of 88 patients with an intracerebral lesion observed by MRI, FET PET was performed, followed by biopsy in 60 patients. The sensitivity of FET PET for high-grade tumors (WHO III-IV) was reported $94 \%$ and for lowgrade tumors (WHO I-II) 68\%. However, there were

\begin{tabular}{|c|c|c|c|c|c|}
\hline Tracer & Mechanism & $\begin{array}{l}\text { No. of } \\
\text { studies }\end{array}$ & $\begin{array}{l}\text { Untreated or } \\
\text { recurrent glioma }\end{array}$ & Advantages & Disadvantages \\
\hline $\mathrm{AMT}^{[38]}$ & $\begin{array}{l}\text { Amino acid PET tracer not } \\
\text { incorporated into proteins but } \\
\text { transported into gliomas via the } \\
\text { kynurenine pathway }\end{array}$ & 1 & Recurrent & $\begin{array}{l}\text { AMT PET could } \\
\text { differentiate between } \\
\text { tumor and XRT necrosis }\end{array}$ & $\begin{array}{l}\text { False positive results } \\
\text { can occur in cortical } \\
\text { dysplasia with } \\
\text { epileptic focus }{ }^{[39]}\end{array}$ \\
\hline MET PET[40] & $\begin{array}{l}\text { MET is transported by the LAT1 } \\
\text { amino acid transporter into } \\
\text { glioma and is incorporated into } \\
\text { proteins }^{[41]}\end{array}$ & 5 & $\begin{array}{l}\text { Upfront }{ }^{[15]} \\
\text { Recurrent } \\
{[41-44]}\end{array}$ & $\begin{array}{l}\text { MET uptake correlated } \\
\text { with prognosis }^{[15]} \\
\text { MET PET could } \\
\text { differentiate between } \\
\text { tumor and XRT } \\
\text { necrosis }^{[40,42]} \\
\text { Correlate with OS and } \\
\text { outcome }^{[43,44]}\end{array}$ & $\begin{array}{l}\text { Short } \\
\text { half-life ( } 20 \text { min) } \\
\text { requiring on site } \\
\text { production; MET } \\
\text { may accumulate in } \\
\text { brain abscesses or } \\
\text { inflammation }{ }^{45]}\end{array}$ \\
\hline FET PET & $\begin{array}{l}\text { FET is an artificial amino acid } \\
\text { transported into active glioma } \\
\text { cells but incorporated into } \\
\text { proteins }^{[46]}\end{array}$ & 5 & $\begin{array}{l}\text { Upfront }{ }^{[47,48]} \\
\text { Recurrent } \\
{[49-51]}\end{array}$ & $\begin{array}{l}\text { FET PET could } \\
\text { differentiate glioma from } \\
\text { nonneoplastic tissue } \\
\text { FET PET distinguished } \\
\text { active tumor from } \\
\text { radiation necrosis; }{ }^{[50,51]} \\
\text { dynamic FET uptake } \\
\text { could differentiate } \\
\text { between high and low } \\
\text { grade tumors }^{[49]}\end{array}$ & $\begin{array}{l}\text { Rare false positive } \\
\text { in granulomatous } \\
\text { conditions and } \\
\text { reactive astogliosis }{ }^{[52]} \\
\text { or false negative } \\
\text { cases }^{[53]}\end{array}$ \\
\hline $\begin{array}{l}\text { FDOPA PET: } \\
\text { (18)F-FDOPA }\end{array}$ & $\begin{array}{l}\text { I-DOPA is the precursor of } \\
\text { dopamine and is transported } \\
\text { physiologically into the brain } \\
\text { and abnormally into the brain } \\
\text { tumors }^{[54]}\end{array}$ & 2 & $\begin{array}{l}\text { Upfront }{ }^{[55]} \\
\text { Recurrent } \\
\text { [55,56] }\end{array}$ & $\begin{array}{l}\text { Correlation of FDOPA } \\
\text { uptake, tumor } \\
\text { proliferation and grade } \\
\text { Diagnostic accuracy of } \\
\text { recurrence similar to } \\
\text { MRI[56] }\end{array}$ & $\begin{array}{l}\text { Diagnostic } \\
\text { usefulness mostly } \\
\text { in upfront gliomas; } \\
\text { limited data }\end{array}$ \\
\hline FLT PET ${ }^{[57,58]}$ & $\begin{array}{l}\text { FLT is an analog of } \\
\text { deoxythymidine, which is } \\
\text { composed of deoxyribose and } \\
\text { the pyrimidine base thymine and } \\
\text { phosphorylated by thymidine } \\
\text { kinase } 1 \text { during DNA synthesis }^{[59]}\end{array}$ & 2 & $\begin{array}{l}\text { Upfront }{ }^{[57]} \\
\text { Recurrent }{ }^{[58]}\end{array}$ & $\begin{array}{l}\text { FLT PET could } \\
\text { differentiate between } \\
\text { high and low grade } \\
\text { tumors } \\
\text { FLT-PET responses } \\
\text { correlated with OS }\end{array}$ & $\begin{array}{l}\text { FLT may accumulate } \\
\text { in benign } \\
\text { lesions with } \mathrm{BBB} \\
\text { disruption }^{[45]}\end{array}$ \\
\hline $\begin{array}{l}\mathrm{CHO} \text { : } \\
\text { (18)F-fluoromethylcholine }\end{array}$ & $\begin{array}{l}\text { During glioma cell proliferation } \\
\text { choline is trapped into the cells } \\
\text { to produce phosphatidylcholine, } \\
\text { a necessary constituent of the } \\
\text { plasma membrane }{ }^{[60]}\end{array}$ & 1 & $\begin{array}{l}\text { Various brain } \\
\text { lesions (tumors or } \\
\text { nontumors) }\end{array}$ & $\begin{array}{l}\text { Higher uptake in } \\
\text { malignant tumors }\end{array}$ & $\begin{array}{l}\text { It may also } \\
\text { accumulate in } \\
\text { various inflammatory } \\
\text { processes }^{[61]}\end{array}$ \\
\hline
\end{tabular}

PET: Positron emission tomography; MRI: Magnetic resonance imaging; XRT: Radiation therapy; BBB: Blood brain barrier; MET: (11)C-methionine; AMT: Alpha-(11)C-methyl-I-tryptophan; FDG: (18)F-flurodeoxyglucose; FET: O-(2-(18)F-fluoroethyl)-I-tyrosine; FDOPA: (18)F-FDOPA; FLT: 3'-fluoro-3' deoxythymidine; PFS: Progression-free survival; OS: Overall survival 
two false-positive cases with postischemic lesions. ${ }^{[52]} \mathrm{A}$ study on differences in the dynamics of FET uptake in gliomas could differentiate between recurrent high and low-grade tumors. ${ }^{[49]}$ In another study, it was shown that an FET-PET with a receiver-operating-characteristic curve analysis, a mean tumor-to-brain ratio of 2.5 was highly specific for tumor rather than nontumor tissue. ${ }^{[4]}$ In 10 patients with recurrent glioma treated with a combination of bevacizumab and irinotecan FET PET could predict treatment failure, thus provided additional information from that obtained by MRI response assessment based on RANO criteria. ${ }^{[50]} \mathrm{A}$ meta-analysis of 13 studies with 462 newly diagnosed untreated patients with primary brain tumors indicated that FET-PET may be an excellent tool for differentiating tumor for non tumoral lesions. ${ }^{[48]}$

Another PET tracers that may be employed for evaluation of brain tumors are (18)F-labeled fluoromethylcholine (18F-FCho) ${ }^{[60]}$ and (11)C-methionine (MET) PET. ${ }^{[31,40,50]}$ MET-PET may aid in the differential diagnosis of tumor recurrence versus radiation necrosis although its specificity and sensitivity have been reported both as $75 \% .^{[42]}$ In patients with glioma, clinical stability induced by temozolomide chemotherapy correlated to a decline or stability of tumor MET uptake on PET. ${ }^{[43]}$ Furthermore, although the standard MET PET did not correlate with survival, a voxel-wise parametric response map analysis of MET PET correlated with OS in 14 patients with recurrent malignant gliomas treated with specific immunotherapy targeting the Wilms tumor 1gene product. ${ }^{[4]}$ The short halflife (20 min) of (11)C limits its use of MET PET to institutions with an onsite cyclotron. A comparison of MET PET with FET-PET (half-life of $120 \mathrm{~min}$ ) in 29 patients with recurrent gliomas showed that both tracers differentiated tumor tissue and treatment-related changes with high sensitivity and specificity suggesting that FET PET could be used in places where an onsite cyclotron is unavailable. ${ }^{[68]}$ FET PET may provide more accurate information in respect of treatment response or failure compared with response assessment based on conventional MRI and RANO criteria, ${ }^{[69]}$ and could reliably distinguish between posttherapeutic treatment related effects and tumor recurrence independently on the employed treatment modality. ${ }^{[51]}$

In addition, there is evidence that FET PET in the management of patients with recurrent glioma treated with a combination of bevacizumab and irinotecan may be cost-effective since it can prevent overtreatment and additional costs, as well as potential side effects to patients. ${ }^{[70]}$

A comparison study between FDG-PET and MET PET in 59 patients with either untreated or recurrent gliomas demonstrated that FDG-PET was a superior test to in vivo predict histologic grade of the tumor compared with MET PET [Table 1]. ${ }^{[14]}$ However, in respect to the low-grade gliomas, MET PET appears to better correlate with overall prognosis and survival rather than FDG PET or conventional MRI, suggesting that both tracers may be complementary during evaluation of gliomas before or after therapies. ${ }^{[15]}$ Similar results in another study suggested that both FDG and MET PET provide useful complementary information assisting surgeons to determine the extent of the surgical resection. ${ }^{[16]}$ In a recent study of 35 patients with suspected recurrent gliomas FDG PET and MET PET were performed during the same day and correlated with subsequent histopathology or MRI/modified Rankin scale and clinical follow-up. The results of this study suggested that MET PET should be preferred over FDG PET when available since it demonstrated higher sensitivity for detection of recurrence (94.7\% vs. $81.2 \%)$ and the same specificity. ${ }^{[21]}$ However, one study found that neither FDG PET or MET PET add any additional information over the conventional MRI regarding prognosis of patients with malignant gliomas. ${ }^{[22]}$ A meta-analysis of 26 heterogeneous studies about several PET tracers for diagnosing recurrent gliomas found that FDG-PET had a summary sensitivity of 0.77 and specificity of 0.78 for any glioma histology, and MET PET had a summary sensitivity of 0.70 and specificity of 0.93 for high-grade glioma. Data were limited for FET and 3'-deoxy-3'-[18F] fluorothymidine (FLT) PET. The authors concluded that apart from FDG and MET PET that seem to have utility during evaluation of glioma recurrence, further studies using direct comparisons between PET tracers and imaging modalities are needed..$^{[23]}$

DOPA: 3,4-dihydroxy-6-(18)F-fluoro-l-phenylalanine (FDOPA) PET tested in a 59 glioma patients (22 with new untreated gliomas and 37 with recurrent tumors) showed that FDOPA uptake was higher in high-grade than in low-grade tumors in newly diagnosed, but not recurrent tumors, suggesting that its usefulness as a noninvasive tumor grading procedure can be only in previously untreated tumors. ${ }^{[5]}$ In recurrent gliomas, FDOPA was able to diagnose the recurrence with a sensitivity of $100 \%$ and specificity of $85.7 \%$ in contrast to $47.6 \%$ and $100 \%$ of FDG PET. ${ }^{[20]}$ In that study, the analysis showed superiority of FDOPA PET compared with FDG-PET to diagnose recurrence in low-grade tumors but no statistical difference in highgrade gliomas. ${ }^{[20]}$

Comparison of FDOPA PET with contrast enhancing MRI scan for detection of tumor recurrence in 35 glioma patients revealed that although both examinations had high sensitivity (100\% vs. 92.3\%), FDOPA PET had much higher specificity (88.9\% vs. 44.4\%) than 
MRI. ${ }^{[56]}$ Furthermore FDOPA PET fused with MRI for anatomic localization provides accurate localization of tracer uptake taking advantage of both techniques. ${ }^{[71]}$

3'-deoxy-3'-[18F]-fluorothymidine is a PET tracer developed for imaging cellular proliferation. In patients with histologically diagnosed primary brain tumors the FLT uptake by the primary tumor could correlate with the grade of malignancy and proliferation index, ${ }^{[72]}$ but occasionally it could result in false positive diagnoses, especially in cases of benign lesions with blood-brain barrier disruption, for example postoperative granuloma. ${ }^{[57]}$ Comparison of FLT PET to MRI with and without contrast in 19 patients with recurrent glioma treated with bevacizumab in combination with irinotecan indicated that both early (1-2 weeks post treatment) and late FLT PET responses (6 weeks) were more significant predictors of overall survival compared with the MRI responses. In this study, metabolic response was defined as more than $25 \%$ reduction in tumor FLT uptake compared with baseline. ${ }^{[58]}$ Furthermore, when compared to FDG PET, FLT PET was reported better in imaging recurrent high-grade tumors, correlating with Ki-67 values, and predicting tumor progression and patient survival.[18] Similarly, comparison of FDG with FDOPA and FLT PET in 15 patients with untreated or recurrent low-grade gliomas demonstrated that clearly FDOPA was the tracer of choice for tumor delineation compared with the other 2 tested tracers. ${ }^{[17]}$ However, another small study in 15 patients with recurrent gliomas reported no advantage of FLT PET compared with FDG PET in discriminating between tumor recurrence and radiation necrosis. ${ }^{[19]}$

FDOPA or FLT PET uptake after bevacizumab treatment may be a useful biomarker for predicting progression-free survival in recurrent gliomas. ${ }^{[73-76]}$

Alpha-(11)C-methyl-l-tryptophan (AMT) PET utilizes the AMT as PET tracer that accumulates into gliomas through the kynurenine pathway, which leads to the production of nicotinamide adenine dinucleotide $\left(\mathrm{NAD}^{+}\right)$from the degradation of the essential amino acid, tryptophan. ${ }^{[77]}$ In 22 patients with possible recurrent glioma on MRI scan tracer uptake by the tumor could differentiate between recurrent glioma and radiation injury. ${ }^{[38]}$ The (18)F-labeled glycosylated Arg-Gly-Asp peptide is a PET tracer that images the integrin alpha (v) beta (3) expression, which may be important considering the integrin inhibitors as potential therapy for glioblastomas. ${ }^{[78]}$

\section{LIMITATIONS}

(18)F-flurodeoxyglucose although represents the most common radiotracer for PET cancer imaging, it is not tumor-specific, since it shows high uptake in benign conditions such as infections and nonspecific inflammatory tissue. ${ }^{[45,79]}$ In viral encephalitis FDG PET usually demonstrates hypermetabolism but focal areas of hypometabolism may also be observed. ${ }^{[80]}$ Brain abscess may also exhibit FDG hypermetabolism making the differential diagnosis between a metastatic tumor and abscess in a patient with systemic cancer impossible with only this test. ${ }^{[81,82]}$ Tuberculomas may also exhibit FDG hypermetabolism in the periphery and hypometabolism in the center. ${ }^{[83]}$

Even though, most of the newer PET tracers demonstrated enhanced tumor-specificity compared with FDG, they also had certain limitations; for example, (11)C-choline can be accumulated in various inflammatory processes, MET in brain abscesses and (18)F-FLT in nonmetastatic reactive lymph nodes. ${ }^{[45]}$

\section{CONCLUSION}

(18)F-flurodeoxyglucose PET, as well as PET with other tracers, may be useful for diagnosis of cerebral gliomas in patients that present with a brain mass and no involvement of other organs in conventional imaging. In addition, PET/CT is helpful in selecting the appropriate site for stereotactic biopsy and in monitoring response to various therapeutic interventions. Finally, upon regrowth of the tumor after the initial treatment, PET/ CT can differentiate between glioma recurrence vs. necrosis from the employed radiation therapy and guide further therapeutic management.

\section{REFERENCES}

1. Kyritsis A. Evaluation and treatment of CNS neoplasms. In: Lechtenberg R, Schutta HS, editors. Neurology Practice Guidelines. New York: Marcel Dekker; 1998. p. 473-96.

2. Kyritsis AP, Levin VA. An algorithm for chemotherapy treatment of recurrent glioma patients after temozolomide failure in the general oncology setting. Cancer Chemother Pharmacol 2011;67:971-83.

3. Hess KR, Wong ET, Jaeckle KA, Kyritsis AP, Levin VA, Prados MD, Yung WK. Response and progression in recurrent malignant glioma. Neuro Oncol 1999;1:282-8.

4. Wong ET, Hess KR, Gleason MJ, Jaeckle KA, Kyritsis AP, Prados MD, Levin VA, Yung WK. Outcomes and prognostic factors in recurrent glioma patients enrolled onto phase II clinical trials. J Clin Oncol 1999;17:2572-8.

5. Zikou AK, Alexiou GA, Kosta P, Goussia A, Astrakas L, Tsekeris P, Voulgaris S, Malamou-Mitsi V, Kyritsis AP, Argyropoulou MI. Diffusion tensor and dynamic susceptibility contrast MRI in glioblastoma. Clin Neurol Neurosurg 2012;114:607-12.

6. Vogelbaum MA, Jost S, Aghi MK, Heimberger AB, Sampson JH, Wen PY, Macdonald DR, Van den Bent MJ, Chang SM. Application of novel response/progression measures for surgically delivered therapies for gliomas: Response Assessment in Neuro-Oncology (RANO) Working Group. Neurosurgery 2012;70:234-43.

7. Nowosielski M, Recheis W, Goebel G, Güler O, Tinkhauser G, Kostron H, Schocke M, Gotwald T, Stockhammer G, Hutterer M. ADC histograms predict response to anti-angiogenic therapy in patients with recurrent high-grade glioma. Neuroradiology 2011;53:291-302. 
8. Mariani G, Bruselli L, Kuwert T, Kim EE, Flotats A, Israel O, Dondi M, Watanabe N. A review on the clinical uses of SPECT/CT. Eur J Nucl Med Mol Imaging 2010;37:1959-85.

9. Okajima K, Ohta Y. Diagnostic imaging of high-grade astrocytoma: heterogeneity of clinical manifestation, image characteristics, and histopathological findings. Brain Nerve 2012;64:1151-7.

10. Alexiou GA, Tsiouris S, Voulgaris S, Kyritsis AP, Fotopoulos AD. Glioblastoma multiforme imaging: the role of nuclear medicine. Curr Radiopharm 2012;5:308-13.

11. Alexiou GA, Tsiouris S, Kyritsis AP, Fotakopoulos G, Goussia A, Voulgaris S, Fotopoulos AD. The value of $99 \mathrm{mTc}$-tetrofosmin brain SPECT in predicting survival in patients with glioblastoma multiforme. J Nucl Med 2010;51:1923-6.

12. Colavolpe C, ChinotO, Metellus, ManciniJ,Barrie M, Bequet-Boucard C, TabouretE, Mundler O, Figarella-Branger D, Guedj E. FDG-PET predicts survival in recurrent high-grade gliomas treated with bevacizumab and irinotecan. Neuro Oncol 2012;14:649-57.

13. Santra A, Kumar R, Sharma P, Bal C, Kumar A, Julka PK, Malhotra A. F-18 FDG PET-CT in patients with recurrent glioma: comparison with contrast enhanced MRI. Eur J Radiol 2012;81:508-13.

14. Borbély K, Nyáry I, Tóth M, Ericson K, Gulyás B. Optimization of semi-quantification in metabolic PET studies with 18F-fluorodeoxyglucose and 11C-methionine in the determination of malignancy of gliomas. J Neurol Sci 2006;246:85-94.

15. Singhal T, Narayanan TK, Jacobs MP, Bal C, Mantil JC 11C-methionine PET for grading and prognostication in gliomas: a comparison study with 18F-FDG PET and contrast enhancement on MRI. J Nucl Med 2012;53:1709-15.

16. Yamaguchi S, Terasaka S, Kobayashi H, Narita T, Hirata K, Shiga S, Usui R, Tanaka S, Kubota K, Murata J, Asaoka K. Combined use of positron emission tomography with (18)F-fluorodeoxyglucose and (11)C-methionine for preoperative evaluation of gliomas. No Shinkei Geka 2010;38:621-8.

17. Tripathi M, Sharma R, D'Souza M, Jaimini A, Panwar P, Varshney R, Datta A, Kumar N, Garg G, Singh D, Grover RK, Mishra AK, Mondal A. Comparative evaluation of F-18 FDOPA, F-18 FDG, and F-18 FLT-PET/CT for metabolic imaging of low grade gliomas. Clin Nucl Med 2009;34:878-83.

18. Chen W, Cloughesy T, Kamdar N, Satyamurthy N, Bergsneider M, Liau L, Mischel P, Czernin J, Phelps ME, Silverman DH. Imaging proliferation in brain tumors with 18F-FLT PET: comparison with 18F-FDG. J Nucl Med 2005;46:945-52.

19. Enslow MS, Zollinger LV, Morton KA, Butterfield RI, Kadrmas DJ, Christian PE, Boucher KM, Heilbrun ME, Jensen RL, Hoffman JM. Comparison of 18F-fluorodeoxyglucose and 18F-fluorothymidine PET in differentiating radiation necrosis from recurrent glioma. Clin Nucl Med 2012;37:854-61.

20. Karunanithi S, Sharma P, Kumar A, Khangembam BC, Bandopadhyaya GP, Kumar R, Gupta DK, Malhotra A, Bal C. 18F-FDOPA PET/CT for detection of recurrence in patients with glioma: prospective comparison with 18F-FDG PET/CT. Eur J Nucl Med Mol Imaging 2013;40:1025-35.

21. Tripathi M, Sharma R, Varshney R, Jaimini A, Jain J, Souza MM, Bal J, Pandey S, Kumar N, Mishra AK, Mondal A. Comparison of F-18 FDG and C-11 methionine PET/CT for the evaluation of recurrent primary brain tumors. Clin Nucl Med 2012;37:158-63.

22. Pötzi C, Becherer A, Marosi C, Karanikas G, Szabo M, Dudczak R, Kletter K, Asenbaum S. 11C methionine and [18F] fluorodeoxyglucose PET in the follow-up of glioblastoma multiforme. J Neurooncol 2007;84:305-14.

23. Nihashi T, Dahabreh IJ, Terasawa T. Diagnostic accuracy of PET for recurrent glioma diagnosis: a meta-analysis. AJNR Am JNeuroradiol 2013;34:944-50, S1-11

24. Raman A, Rothrock JF, Liu HG, Mountz JM. Differentiation of benign $v s$. malignant mass in a postirradiation cerebral arteriovenous malformation by 2-deoxy-2-[18F] fluoro-D-glucose positron emission tomography. Mol Imaging Biol 2004;6:1-6.

25. Polyzoidis KS, Miliaras G, Pavlidis N. Brain metastasis of unknown primary: a diagnostic and therapeutic dilemma. Cancer Treat Rev 2005;31:247-55.
26. Go KG, Pruim J, Que TH, Vaalburg W, Haaxma-Reiche H. Evaluation of dissemination studies with FDG whole-body positron emission tomography in patients with suspected metastatic tumours of brain and spine. Acta Neurochir (Wien) 2000;142:627-31.

27. Jeong HJ, Chung JK, Kim YK, Kim CY, Kim DG, Jeong JM, Lee DS Jung HW, Lee MC. Usefulness of whole-body (18)F-FDG PET in patients with suspected metastatic brain tumors. $J$ Nucl Med 2002;43:1432-7.

28. Klee B, Law I, Højgaard L, Kosteljanetz M. Detection of unknown primary tumours in patients with cerebral metastases using whole-body $18 \mathrm{~F}$-flouorodeoxyglucose positron emission tomography. Eur J Neurol 2002;9:657-62.

29. Campos S, Davey P, Hird A, Pressnail B, Bilbao J, Aviv RI, Symons S, Pirouzmand F, Sinclair E, Culleton S, Desa E, Goh P, Chow E. Brain metastasis from an unknown primary, or primary brain tumour? A diagnostic dilemma. Curr Oncol 2009;16:62-6.

30. Kyritsis AP, Levin VA, Yung WK, Leeds NE. Imaging patterns of multifocal gliomas. Eur J Radiol 1993;16:163-70.

31. Hanson MW, Glantz MJ, Hoffman JM, Friedman AH, Burger PC, Schold SC, Coleman RE. FDG-PET in the selection of brain lesions for biopsy. J Comput Assist Tomogr 1991;15:796-801.

32. Kawai N, Miyake K, Nishiyama Y, Yamamoto Y, Miki A, Haba R, Imai T, Tamiya T, Nagao S. Targeting optimal biopsy location in basal ganglia germinoma using (11)C-methionine positron emission tomography. Surg Neurol 2008;70:408-13.

33. Grosu AL, Piert M, Weber WA, Jeremic B, Picchio M Schratzenstaller U, Zimmermann FB, Schwaiger M, Molls M. Positron emission tomography for radiation treatment planning. Strahlenther Onkol 2005; 181:483-99.

34. Schaller B. Usefulness of positron emission tomography in diagnosis and treatment follow-up of brain tumors. Neurobiol Dis 2004; 15:437-48.

35. Santra A, Kumar R, Sharma P, Bal C, Julka PK, Malhotra A. F-18 FDG PET-CT for predicting survival in patients with recurrent glioma: a prospective study. Neuroradiology 2011;53:1017-24.

36. Charnley N, West CM, Barnett CM, Brock C, Bydder GM, Glaser M, Newlands ES, Swindell R, Matthews J, Price P. Early change in glucose metabolic rate measured using FDG-PET in patients with high-grade glioma predicts response to temozolomide but not temozolomide plus radiotherapy. Int $J$ Radiat Oncol Biol Phys 2006;66:331-8.

37. Bohndiek SE, Brindle KM. Imaging and 'omic' methods for the molecular diagnosis of cancer. Expert Rev Mol Diagn 2010;10:417-34.

38. Alkonyi B, Barger GR, Mittal S, Muzik O, Chugani DC, Bahl G, Robinette NL, Kupsky WJ, Chakraborty PK, Juhász C. Accurate differentiation of recurrent gliomas from radiation injury by kinetic analysis of a-11C-methyl-L-tryptophan PET. $J$ Nucl Med 2012;53:1058-64.

39. Kumar A, Asano E, Chugani HT. A- $\left[{ }^{11} \mathrm{C}\right]$-methyl-L-tryptophan PET for tracer localization of epileptogenic brain regions: clinical studies. Biomark Med 2011;5:577-84.

40. Arbizu J, Tejada S, Marti-Climent JM, Diez-Valle R, Prieto E, Quincoces G, Vigil C, Idoate MA, Zubieta JL, Peñuelas I, Richter JA Quantitative volumetric analysis of gliomas with sequential MRI and ${ }^{11} \mathrm{C}$-methionine PET assessment: patterns of integration in therapy planning. Eur J Nucl Med Mol Imaging 2012;39:771-81.

41. Bustany P, Chatel M, Derlon JM, Darcel F, Sgouropoulos P, Soussaline F, Syrota A. Brain tumor protein synthesis and histological grades: a study by positron emission tomography (PET) with C11-L-Methionine. J Neurooncol 1986;3:397-404

42. Terakawa Y, Tsuyuguchi N, Iwai Y, Yamanaka K, Higashiyama S, Takami T, Ohata K. Diagnostic accuracy of 11C-methionine PET for differentiation of recurrent brain tumors from radiation necrosis after radiotherapy. J Nucl Med 2008;49:694-9.

43. Galldiks N, Kracht LW, Burghaus L, Thomas A, Jacobs AH, Heiss WD, Herholz K. Use of 11C-methionine PET to monitor the effects of temozolomide chemotherapy in malignant gliomas. Eur J Nucl Med Mol Imaging 2006;33:516-24. 
44. Chiba Y, Kinoshita M, Okita Y, Tsuboi A, Isohashi K, Kagawa N, Fujimoto Y, Oji Y, Oka Y, Shimosegawa E, Morita S, Hatazawa J, Sugiyama H, Hashimoto N, Yoshimine T. Use of (11)C-methionine PET parametric response map for monitoring WT1 immunotherapy response in recurrent malignant glioma. $J$ Neurosurg 2012;116:835-42.

45. van Waarde A, Elsinga PH. Proliferation markers for the differential diagnosis of tumor and inflammation. Curr Pharm Des 2008;14:3326-39.

46. Wester HJ, Herz M, Weber W, Heiss P, Senekowitsch-Schmidtke R, Schwaiger M, Stöcklin G. Synthesis and radiopharmacology of O-(2-[18F] fluoroethyl)-L-tyrosine for tumor imaging. J Nucl Med 1999;40:205-12.

47. Rapp M, Heinzel A, Galldiks N, Stoffels G, Felsberg J, Ewelt C, Sabel M, Steiger HJ, Reifenberger G, Beez T, Coenen HH, Floeth FW, Langen KJ. Diagnostic performance of 18F-FET PET in newly diagnosed cerebral lesions suggestive of glioma. J Nucl Med 2013;54:229-35.

48. Dunet V, Rossier C, Buck A, Stupp R, Prior JO. Performance of 18F-fluoro-ethyl-tyrosine (18F-FET) PET for the differential diagnosis of primary brain tumor: a systematic review and Metaanalysis. J Nucl Med 2012;53:207-14.

49. Pöpperl G, Kreth FW, Herms J, Koch W, Mehrkens JH, Gildehaus FJ, Kretzschmar HA, Tonn JC, Tatsch k. Analysis of 18F-FET PET for grading of recurrent gliomas: is evaluation of uptake kinetics superior to standard methods? J Nucl Med 2006;47:393-403.

50. Galldiks N, Rapp M, Stoffels G, Fink GR, Shah NJ, Coenen HH, Sabel M, Langen KJ. Response assessment of bevacizumab in patients with recurrent malignant glioma using [18F] Fluoroethyl-L-tyrosine PET in comparison to MRI. Eur J Nucl Med Mol Imaging 2013;40:22-33.

51. Pöpperl G, Götz C, Rachinger W, Gildehaus FJ, Tonn JC, Tatsch K. Value of O-(2-[18F] fluoroethyl)- L-tyrosine PET for the diagnosis of recurrent glioma. Eur J Nucl Med Mol Imaging 2004;31:1464-70.

52. Pichler R, Dunzinger A, Wurm G, Pichler J, Weis S, Nussbaumer K, Topakian R, Aigner RM. Is there a place for FET PET in the initial evaluation of brain lesions with unknown significance? Eur J Nucl Med Mol Imaging 2010;37:1521-8.

53. Pichler R, Wurm G, Nussbaumer K, Kalev O, Silyé R, Weis S. Sarcoidois and radiation-induced astrogliosis causes pitfalls in neuro-oncologic positron emission tomography imaging by O-(2-[18F] fluoroethyl)-L-tyrosine. J Clin Oncol 2010;28:e753-5.

54. Heiss WD, Wienhard K, Wagner R, Lanfermann H, Thiel A, Herholz K, Pietrzyk U. F-Dopa as an amino acid tracer to detect brain tumors. J Nucl Med 1996;37:1180-2.

55. Fueger BJ, Czernin J, Cloughesy T, Silverman DH, Geist CL, Walter MA, Schiepers C, Nghiemphu P, Lai A, Phelps ME, Chen W. Correlation of 6-18F-fluoro-L-dopa PET uptake with proliferation and tumor grade in newly diagnosed and recurrent gliomas. $J \mathrm{Nucl}$ Med 2010;51:1532-8.

56. Karunanithi S, Sharma P, Kumar A, Khangembam BC, Bandopadhyaya GP, Kumar R, Goenka A, Gupta DK, Malhotra A, Bal C. Comparative diagnostic accuracy of contrast-enhanced MRI and (18)F-FDOPA PET-CT in recurrent glioma. Eur Radiol 2013;23:2628-35.

57. Saga T, Kawashima H, Araki N, Takahashi JA, Nakashima Y, Higashi T, Oya N, Mukai T, Hojo M, Hashimoto N, Manabe T, Hiraoka M, Togashi K. Evaluation of primary brain tumors with FLT-PET: usefulness and limitations. Clin Nucl Med 2006;31:774-80.

58. Chen W, Delaloye S, Silverman DH, Geist C, Czernin J, Sayre J, Satyamurthy N, Pope W, Lai A, Phelps ME, Cloughesy T. Predicting treatment response of malignant gliomas to bevacizumab and irinotecan by imaging proliferation with [18F] fluorothymidine positron emission tomography: a pilot study. $J$ Clin Oncol 2007;25:4714-21.

59. Miyake K, Shinomiya A, Okada M, Hatakeyama T, Kawai N, Tamiya T. Usefulness of FDG, MET and FLT-PET studies for the management of human gliomas. $J$ Biomed Biotechnol 2012;2012:205818.
60. Mertens K, Bolcaen J, Ham H, Deblaere K, Van den Broecke C, Boterberg T, De Vos F, Goethals I. The optimal timing for imaging brain tumours and other brain lesions with 18F-labelled fluoromethylcholine: a dynamic positron emission tomography study. Nucl Med Commun 2012;33:954-9.

61. Huang Z, Zuo C, Guan Y, Zhang Z, Liu P, Xue F, Lin X. Misdiagnoses of 11C-choline combined with 18F-FDG PET imaging in brain tumours. Nucl Med Commun 2008;29:354-8.

62. Walter F, Cloughesy T, Walter MA, Lai A, Nghiemphu P, Wagle N, Fueger B, Satyamurthy N, Phelps ME, Czernin J. Impact of 3,4-dihydroxy-6-18F-fluoro-L-phenylalanine PET/CT on managing patients with brain tumors: the referring physician's perspective. J Nucl Med 2012;53:393-8.

63. Galldiks N, Stoffels G, Filss CP, Piroth MD, Sabel M, Ruge MI, Herzog H, Shah NJ, Fink GR, Coenen HH, Langen KJ. Role of O-(2-(18) F-fluoroethyl)-L-tyrosine PET for differentiation of local recurrent brain metastasis from radiation necrosis. J Nucl Med 2012;53:1367-74.

64. Lau EW, Drummond KJ, Ware RE, Drummond E, Hogg A, Ryan G, Grigg A, Callahan J, Hicks RJ. Comparative PET study using F-18 FET and F-18 FDG for the evaluation of patients with suspected brain tumour. J Clin Neurosci 2010;17:43-9.

65. Jansen NL, Graute V, Armbruster L, Suchorska B, Lutz J, Eigenbrod S, Cumming P, Bartenstein P, Tonn JC, Kreth FW, la Fougère C. MRI-suspected low-grade glioma: is there a need to perform dynamic FET PET? Eur J Nucl Med Mol Imaging 2012;39:1021-9.

66. Floeth FW, Sabel M, Stoffels G, Pauleit D, Hamacher K, Steiger HJ, Langen KJ. Prognostic value of 18F-fluoroethyl-L-tyrosine PET and MRI in small nonspecific incidental brain lesions. J Nucl Med 2008;49:730-7.

67. Sato N, Inoue T, Tomiyoshi K, Aoki J, Oriuchi N, Takahashi A, Otani T, Kurihara H, Sasaki T, Endo K. Gliomatosis cerebri evaluated by 18Falpha-methyl tyrosine positron-emission tomography. Neuroradiology 2003;45:700-7.

68. Grosu AL, AstnerST, RiedelE, NiederC, Wiedenmann N, Heinemann F, Schwaiger M, Molls M, Wester HJ, Weber WA. An interindividual comparison of O-(2-[18F] fluoroethyl)-L-tyrosine (FET)- and L-[methyl-11C] methionine (MET)-PET in patients with brain gliomas and metastases. Int $J$ Radiat Oncol Biol Phys 2011;81:1049-58.

69. Hutterer M, Nowosielski M, Putzer D, Waitz D, Tinkhauser G, Kostron H, Muigg A, Virgolini IJ, Staffen W, Trinka E, Gotwald T, Jacobs AH, Stockhammer G. O-(2-18F-fluoroethyl)-L-tyrosine PET predicts failure of antiangiogenic treatment in patients with recurrent high-grade glioma. J Nucl Med 2011;52:856-64.

70. Heinzel A, Müller D, Langen KJ, Blaum M, Verburg FA, Mottaghy FM, Galldiks N. The use of O-(2-18F-fluoroethyl)-L-tyrosine PET for treatment management of bevacizumab and irinotecan in patients with recurrent high-grade glioma: a cost-effectiveness analysis. J Nucl Med 2013;54:1217-22.

71. Ledezma CJ, Chen W, Sai V, Freitas B, Cloughesy T, Czernin J, Pope W. 18F-FDOPA PET/MRI fusion in patients with primary/ recurrent gliomas: initial experience. Eur J Radiol 2009;71:242-8.

72. Spence AM, Muzi M, Link JM, O'Sullivan F, Eary JF, Hoffman JM, Shankar LK, Krohn KA. NCI-sponsored trial for the evaluation of safety and preliminary efficacy of 3'-deoxy-3'-[18F] fluorothymidine (FLT) as a marker of proliferation in patients with recurrent gliomas: preliminary efficacy studies. Mol Imaging Biol 2009;11:343-55.

73. Harris RJ, Cloughesy TF, Pope WB, Nghiemphu PL, Lai A, Zaw T, Czernin J, Phelps ME, Chen W, Ellingson BM. 18F-FDOPA and 18F-FLT positron emission tomography parametric response maps predict response in recurrent malignant gliomas treated with bevacizumab. Neuro Oncol 2012;14:1079-89.

74. Schwarzenberg J, Czernin J, Cloughesy TF, Ellingson BM, Pope WB, Geist C, Dahlbom M, Silverman DH, Satyamurthy N, Phelps ME, Chen W. 3'-deoxy-3'-18F-fluorothymidine PET and MRI for early survival predictions in patients with recurrent malignant glioma treated with bevacizumab. J Nucl Med 2012;53:29-36.

75. Idema AJ, Hoffmann AL, Boogaarts HD, Troost EG, Wesseling P, Heerschap A, van der Graaf WT, Grotenhuis JA, Oyen WJ. 
3'-Deoxy-3'-18F-fluorothymidine PET-derived proliferative volume predicts overall survival in high-grade glioma patients. J Nucl Med 2012;53:1904-10.

76. Wardak M, Schiepers C, Cloughesy TF, Dahlbom M, Phelps ME, Huang SC. ${ }^{18} \mathrm{~F}$-FLT and ${ }^{18} \mathrm{~F}$-FDOPA PET kinetics in recurrent brain tumors. Eur J Nucl Med Mol Imaging 2014;41:1199-209.

77. Chen Y, Guillemin GJ. Kynurenine pathway metabolites in humans: disease and healthy States. Int $J$ Tryptophan Res 2009;2:1-19.

78. Schnell O, Krebs B, Carlsen J, Miederer I, Goetz C, Goldbrunner RH, Wester HJ, Haubner R, Pöpperl G, Holtmannspötter M, Kretzschmar HA, Kessler H, Tonn JC, Schwaiger M, Beer AJ. Imaging of integrin alpha $(\mathrm{v})$ beta (3) expression in patients with malignant glioma by [18F] Galacto-RGD positron emission tomography. Neuro Oncol 2009;11:861-70.

79. Hirata K, Shiga T, Fujima N, Manabe O, Usui R, Kuge Y, Tamaki N. (11)C-Methionine positron emission tomography may monitor the activity of encephalitis. Acta Radiol 2012;53:1155-7.

80. Lee BY, Newberg AB, Liebeskind DS, Kung J, Alavi A. FDG-PET findings in patients with suspected encephalitis. Clin Nucl Med 2004;29:620-5.
81. Mascarenhas NB, Lam D, Lynch GR, Fisher RE. PET imaging of cerebral and pulmonary Nocardia infection. Clin Nucl Med 2006;31:131-3.

82. Tsuyuguchi N, Sunada I, Ohata K, Takami T, Nishio A, Hara M, Kawabe J, Okamura T, Ochi H. Evaluation of treatment effects in brain abscess with positron emission tomography: comparison of fluorine-18-fluorodeoxyglucose and carbon-11-methionine. Ann Nucl Med 2003;17:47-51.

83. Kang K, Lim I, Roh JK. Positron emission tomographic findings in a tuberculous brain abscess. Ann Nucl Med 2007;21:303-6.

Cite this article as: Assimakopoulos A, Polyzoidis K, Sioka C. Positron emission tomography imaging in gliomas. Neuroimmunol Neuroinflammation 2014;1(3):107-14.

Source of Support: Nil. Conflict of Interest: No.

Received: 28-07-2014; Accepted: 27-08-2014 